\title{
DANDE
}

VOLUME 2 (2), NOVEMBER 2018

\section{Editorial: Special Issue on Womanism \& Culture}

Articles in this Issue celebrate womanhood, aspects that characterize it and directs our attention to gendered discourses that seek to unearth the idea that women have always fought for their rights and actively participated in various ways in the sustainable development of African societies. Articles approach the concept of 'Womanhood' or 'Womanism' in its localized and broadest sense drawing on key cultural issues on which power struggles or otherwise emanate from. They point out areas of success showing what African societies can achieve through womanhood or other cultural dynamics. As womanhood seeks to maintain an inclusive culture in African societies, some aspects of sustainable development are addressed. Drawing much from the Zimbabwean realities and the region, these articles reveal, in a subtle way, efforts by women actively participating in discourses of nationhood as well as recommending in considerable ways how on one hand women make significant contributions in national culture; on the other hand, aspects of healing and reconciliation are also subtlety addressed. The articles augment voices on gender discourses, culture and nation building, however, in a very unique way.

In unpacking some dynamics around womanism, Moyo argues that women and their experiences are essential to the spirituality and ministry of reconciliation. He notes that seemingly endless domination of women by men has forced them to come up with alternatives to their 'freedom' with strong desire to create communities of reconciliation outside of the usual paths of power and domination. It is shown that women exude the power to go beyond the hurts, violence, rape and humiliation to build a nation and transform societies against endemic culture of violence. Moyo nearly comes short of expressing that men are responsible for all the violence in the world whereas women have the burden of having to deal with the effects, mop up the 'dirty' and come in to play a crucial role in healing the violated world largely caused by men's misplaced desires to dominate.

Women writers have also contributed significantly on the literary scene and Dlodlo explores Ndebele poems contributed by women as published by the Zimbabwe Women Writers. Not only does this expose the work of Zimbabwe Women Writers to promote literary works by women, but reveals women voices and their experiences as reflected in works of art. Dlodlo explores women's articulation of their emancipation and empowerment in a Ndebele anthology, Inkondlo, published in 1998. She argues that Inkondlo deconstructs the feminist way of thinking which guides the publisher. 
While Dlodlo explores Ndebele poetry, Naidoo invites the reader to rethink the feminist agenda in Zimbabwean female authored literary texts. Naidoo takes us through Virginia Phiri's Destiny and Highway Queen as well as Violet Masilo's The African Tea Cosy; to argue that, Zimbabwean female authorship is flavoured with precepts of African feminism(s) in its representations of African women's agency in gender adversities. Although female authored, she notes that the African feminist text in general is concerned with the survival of both men and women.

Because the survival of both men and women is crucial in cultural as well as nation building, Mahomva discusses in his article the Umdala wethu legacy and the multifaceted political fatherhood functions of Joshua Nkomo in Zimbabwe's contemporary politics. Quite thought provoking in the article is the subtle ushering in of questions along aspects of 'motherhood' as well in nation building.

In popular culture, Mabuto and Saidi reveal the nihilistic culture that characterize musical genres like Zimdancehall which has become popular with contemporary youths in Zimbabwe. The article reveals the existential crisis youths in Zimbabwe face due to economic as well as other negative social forces reflected in the songs and thus conditioning them to align themselves to rather destructive behaviours. It is these ultimate negative misogynistic behaviours that are found characterising contemporary Zimbabwe as such a threat to cultural as well as national development.

In taking youths' social challenges further, Chikoko et al address adolescent commercial sex work realities. Chikoko et al show how adolescent street girls use traditional medicine in their commercial sex work demonstrating their agency in Harare. Society is called upon to rethink as well as see the extent to which the girl child in urban setups is not only violated but how adolescent-street girls are negotiating for space in contemporary Zimbabwe at the same time problematizing use of indigenous knowledge systems in modern Zimbabwe.

Matiza reengages representation of women in newspapers, The Chronicle and The NewsDay via the cartoons during the Operation Restore Legacy era. So critical is the interest in the role of women and their portrayal during the period under discussion. Muranda, however, takes the reader to aspects of reflections on death through song among the Shona people of Zimbabwe. Jongore et al. unravels power relations in the electronic advertising texts such as those aired on television drawing very pertinent cultural realities in the world of advertising.

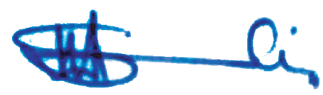

Umali Saidi

Editor

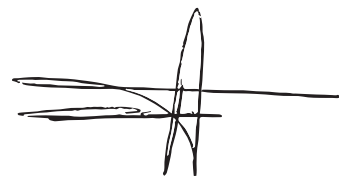

Charles Pfukwa

Editor-in-Chief 